\title{
Pelatihan dan Pendampingan Implementasi Aplikasi Wordwall dalam Pembelajaran Matematika Bagi Guru Kelas Rendah Sekolah Dasar Inpres Maulafa Kota Kupang
}

\author{
Juliana M. H. Nenohai ${ }^{1}$, Siprianus S. Garak ${ }^{2}$, \\ Christine K. Ekowati ${ }^{3}$, dan Patrisius A. Udil ${ }^{4 *}$ \\ 1,2,3,4 Pendidikan Matematika, FKIP Universitas Nusa Cendana \\ *Correspondent Author Email: afrisno.udil@staf.undana.ac.id
}

\begin{abstract}
The Covid-19 pandemic has changed face-to-face (offline) learning into online learning. This requires teachers to be able to adapt to utilizing technology-based learning media. Meanwhile, at the same time, teachers are not used to and have not been able to use various technology-based media in learning. One of the media that could be used is the wordwall application. This application is considered suitable because the appearance and operation are quite simple. In addition, this application can also be used as a learning media, a learning resource, and an assessment instrument. Therefore, training activities and mentoring in the implementation of wordwall applications in learning mathematics is one of the important and urgent needs for teachers today, especially in SD Inpres Maulafa, East Nusa Tenggara. This activity is carried out in training and mentoring through the material presentation, discussion, demonstrations and simulations, working in the group, and assistance. This activity showed that the participants were enthusiastic, active, and participative in participating in the training and mentoring. In addition, this activity can help participants overcome problems in designing thematic lessons. This activity can also increase teachers' knowledge about the application of technology to create learning media in the form of innovative elementary mathematics online learning media, namely through technical training in making learning media with wordwall applications in mathematics learning for teachers. Furthermore, this activity has also been able to increase the insight and ability of teachers to implement media in learning activities, namely through assistance in making learning designs using wordwall applications and assistance in implementing (strategy) learning using wordwall media.
\end{abstract}

Keywords: Training and Mentoring, Wordwall Application, Learning Media, Mathematics, Thematic Learning

\section{Pendahuluan}

\subsection{Analisis Situasi}

Pembelajaran pada dasarnya dimaknai sebagai proses interaksi antara pendidik dan peserta didik melalui lingkungan belajar yang kondusif dalam upaya untuk mengoptimalkan potensi peserta didik sehingga menjadi pribadi yang bersikap, berperilaku, berkemampuan, dan berketerampilan baik. Hal ini setidaknya digariskan dalam Undang-Undang Nomor 20 Tahun 2003 tentang Sistem Pendidikan Nasional yang menyebutkan pembelajaran sebagai proses interaksi peserta didik dengan pendidik dan sumber belajar pada suatu lingkungan belajar. Dalam posisi dan sudut pandang pendidik, pembelajaran dimaknai sebagai upaya pendidik untuk membelajarkan peserta didik dengan memanfaatkan berbagai sumber daya yang tersedia sebagai sumber dan lingkungan belajar sehingga tercapainya tujuan instruksional 
pembelajaran. Oleh karena itu, pendidik dituntut untuk mampu memanfaatkan berbagai sumber daya yang tersedia pada lingkungan belajarnya untuk membantu peserta didik mencapai tujuan pembelajaran yang diinginkan.

Situasi pandemi Covid-19 mengubah pembelajaran tatap muka di kelas menjadi pembelajaran dalam jaringan (daring/online). Pembalajaran daring merupakan pembelajaran mandiri yang dilakukan secara online melalui aplikasi pembelajaran maupun jejaring sosial dan menuntut kemandirian siswa dalam mencerna dan memahami berbagai informasi yang dibelajarkan (Nissa \& Renoningtyas, 2021). Kondisi ini tentu saja menghadirkan tantangan tersendiri baik bagi siswa untuk dapat beradaptasi dengan situasi yang ada. Wafiqni dan Putri (2021) mengatakan bahwa pembelajaran daring yang tidak melakukan tatap muka langsung dapat menyebabkan fokus peserta didik berkurang serta. Selain itu karena waktu pembelajaran yang menjadi lebih singkat mengakibatkan keutuhan pembelajaran yang meliputi pembukaan, kegiatan inti (isi) dan penutup terabaikan.

Selain itu, pembelajaran daring juga menuntut guru untuk mampu beradaptasi dan kreatif dalam membelajarkan materi menggunakan berbagai media dan platform pembelajaran yang ada. Hal ini justru masih menjadi tantangan tersendiri bagi guru yang masih sebagian besar kesulitan untuk memanfaatkan berbagai media berbasis IT dalam membelajarkan materi (Nissa \& Renoningtyas, 2021). Guru-guru masih belum siap menghadapi perubahan yang ada serta masih minim pengetahuan terkait pemanfaatan media pembelajaran berbasis teknologi (Sari \& Yarza, 2021). Dalam konteks pembelajaran matematika SD yang berbasis pembelajaran tematik, tantangan yang juga dialami guru adalah bagaimana pembelajaran dikemas dalam bentuk aktivitas yang menyenangkan melalui pemanfaatan berbagai media dan teknologi pembelajaran yang ada. Hal ini setidaknya masih menjadi masalah yang dialami oleh guru-guru kelas rendah SD Inpres Maulafa Kota Kupang berdasarkan wawancara dan observasi awal bersama guru-guru di SD Inpres Maulafa Kota Kupang. Guru masih kesulitan untuk merancang pembelajaran tematik yang memanfaatkan media pembelajaran berbasis teknologi untuk menunjang pembelajaran daring. Hal ini dikarenakan kurangnya pengetahuan guru terkait media pembelajaran yang dimaksud serta minimnya kemampuan merancang pembelajaran yang memanfaatkan media berbasis teknologi untuk menunjang pembelajaran dari. Pada akhirnya, guru memanfaatkan media seperti zoom dan googlemeet namun pembelajaran matematika lebih banyak melalui penjelasan secara langsung oleh guru yang didominasi dengan pemberian ceramah dalam mengajar sehingga menyebabkan pembelajaran menjadi kurang bermakna, rendahnya partisipasi dan motivasi siswa berkurang.

Permasalahan di atas sejatinya dapat diantisapsi dengan memanfaatkan berbagai media pembelajaran berbasis teknologi yang sederhana, interaktif, dan relevan dengan koteks siswa SD. Beberapa media pembelajaran yang dapat digunakan untuk meningkatkan motivasi belajar siswa karena dapat membangun pembelajaran yang interaktif dan mudah diakses antara lain wordwall, quizizz, schoology, kahoot, dan berbagai media lainnya. Salah satu media pembelajaran yang disebutkan di atas yaitu aplikasi wordwall dipandang cocok dan tepat digunakan untuk mengatasi permasalahan yang telah dipaparkan sebelumnya. Wordwall adalah aplikasi berbasi web (webbased application) yang memungkinkan guru untuk merancang pembelajaran dan menyediakan sumber belajar yang menarik dan interaktif bagi siswa. Wordwall dapat dimanfaatkan sebagai media pembelajaran, sumber belajar, sekaligus instrumen penilaian (Sari \& Yarza, 2021) yang berbasis permainan menarik (Nissa \& 
Renoningtyas, 2021) dengan berbagai templete yang disediakan. Di samping itu, wordwall juga menampilkan berbagai kreasi guru (Wafiqni \& Putri, 2021) yang dapat dijadikan referensi bagi guru lain dalam merancang dan mengembangkan media pembelajaran.

Upaya untuk mengatasi permasalahan pemahaman yang masih kurang dalam merancang pembelajaran tematik serta membuat dan menggunakan media pembelajaran yang inovatif, maka perlu dilakukan suatu kegiatan pelatihan dan pendampingan pembuatan dan implementasi media pembelajaran yang kreatif, inovatif, interaktif, serta menunjang pembelajaran daring. Oleh karena itu, para guru dan kepala sekolah bersama dengan tim Program Kemitraan Masyarakat Prodi Pendidikan Matematika Universitas Nusa Cendana memandang perlu untuk mengadakan kegiatan pelatihan dan pendampingan implementasi aplikasi wordwall dalam pembelajaran matematika bagi guru kelas rendah Sekolah Dasar Inpres Maulafa Kota Kupang.

\subsection{Permasalahan Mitra}

Berdasarkan analisis situasi/masalah di atas maka sesungguhnya permasalahan utama bagi para guru adalah kesulitan dalam merancang pembelajaran tematik dan menggunakan media pembelajaran yang inovatif untuk pembelajaran matematika dan mengimplementasikannya dalam pembelajaran karena kurangnya pengetahuan dan pemahaman yang dimiliki guru.

Kesulitan para guru dalam membuat dan menggunakan media pembelajaran antara lain diuraikan sebagai berikut.

a. Keterbatasan pengetahuan tentang pembelajaran tematik di SD.

b. Keterbatasan pengetahuan tentang media pembelajaran yang dapat digunakan untuk menjelaskan materi matematika SD.

c. Keterbatasan pengetahuan dan keterampilan tentang media pembelajaran matematika SD dan cara menggunakannya dalam pembelajaran.

d. Motivasi para guru untuk melaksanakan inovasi pelaksanaan pembelajaran sangat rendah, karena mereka jarang mengikuti ataupun diikutsertakan dalam kegiatan- kegiatan ilmiah terkait.

\section{Solusi Masalah}

Berdasarkan permasalahan yang dihadapi oleh mitra, beberapa alternatif solusi yang dapat ditawarkan adalah sebagai berikut.

a. Membantu para guru mengatasi masalah dalam merancang pembelajaran Tematik. Dalam hal ini, bantuan yang dimaksud diberikan dalam bentuk pelatihan dan pendampingan bagi guru-guru pada sekolah mitra dalam merancang dan mendesain pembelajaran tematik.

b. Menambah pengetahuan para guru tentang penerapan teknologi untuk membuat media pembelajaran berupa media pembelajaran daring matematika SD yang inovatif yakni melalui pelatihan teknis membuat media pembelajaran dengan aplikasi wordwall dalam pembelajaran matematika bagi guru-guru pada sekolah mitra.

c. Menambah wawasan dan kemampuan guru untuk mengimplementasikan media dalam kegiatan pembelajaran yakni melalui pendampingan membuat desain pembelajaran menggunakan aplikasi wordwall dan pendampingan pelaksanaan (desain) pembelajaran menggunakan media wordwall. 
Beberapa solusi di atas ditawarkan untuk bisa mengatasi berbagai persoalan yang dialami guru-guru pada sekolah mitra. Melalui solusi yang ditawarkan diharapkan guru-guru pada sekolah mitra dapat secara mandiri mengembangkan potensinya untuk optimalisasi kegiatan pembelajaran di masa yang akan datang. Lebih lanjut, guru-guru pada sekolah mitra juga dapat mengoptimalkan kemampuannya dalam melaksanakan pembelajaran yang menarik dan interaktif dengan memanfaatkan media berbasis teknologi dalam bentuk aplikasi wordwall sebagai salah satu upaya untuk mengatasi keterbatasan dan kesulitan pembelajaran selama masa pandemic covid 19 di sekolah mitra.

\section{Metode Pelaksanaan}

Kegiatan pengabdian masyarakat ini dilakukan dalam bentuk pelatihan dan pendampingan yang dilakukan secara offline. Metode yang digunakan antara lain workshop (pemaparan materi, tanya jawab, dan diskusi), pelatihan, dan pendampingan.

\subsection{Pelatihan}

\subsubsection{Materi pelatihan}

Materi pelatihan meliputi beberapa materi teoritis dan praktis yang menunjang dan mendukung pemahaman konseptual dan praktis guru-guru terkait pembelajaran interaktif, pembelajaran tematik, tingkat perkembangan peserta didik SD, media pembelajaran, dan pengenalan aplikasi wordwall sebagai media pembelajaran berbasis teknologi.

Selain itu, materi pelatihan juga disertai dengan materi tentang pelatihan teknis mendesain pembelajaran matematika dengan menggunakan aplikasi wordwall sebagai salah satu materi penting yang dapat membekali guru-guru dengan pemahaman dan pengetahuan praktis mendesain pembelajaran dengan aplikasi wordwall. Guru-guru juga dibekali dengan materi terkait pemanfaatan aplikasi wordwall sebagai media pembelajaran dalam pembelajaran matematika.

\subsubsection{Metode dan tahapan pelatihan}

Pelatihan dilakukan secara offline dalam bentuk pemaparan materi, tanya jawab, diskusi dan simulasi, serta kerja kelompok. Para guru diberikan penjelasan tentang pembelajaran tematik khusunya pada pembelajaran matematika, media pembelajaran matematika SD dan teori serta cara menggunakan media aplikasi wordwall. Para guru dilatih menggunakan media aplikasi wordwall sesuai dengan teori dan petunjuk yang diberikan.

Kemudian para guru diberikan kesempatan untuk bekerja dalam kelompok untuk mendesain media pembelajaran dengan aplikasi wordwall. Para guru dibentuk dalam beberapa kelompok selanjutnya diminta untuk mendesain pembelajaran secara berkelompok. Hasil desain tersebut kemudian dipresentasikan untuk didiskusikan bersama, terutama untuk memberikan penekanan pada aspek pemanfaatannya dalam konteks pembelajaran matematika SD.

\subsection{Pendampingan}

Pendampingan dilakukan melalui diskusi bersama seluruh peserta secara reguler sesuai jadwal yang disepakati. Diskusi untuk membahas desain pembelajaran yang dibuat oleh para guru serta saling melengkapi antara satu dengan yang lain. Dengan mengetahui desain pembelajaran dari setiap teman gurunya pada saat diskusi, maka diharapkan pemahaman para 
guru akan lebih baik dan desain yang dihasilkan juga lebih baik. Materi diskusi adalah rancangan desain pembelajaran yang dibuat oleh guru.

Selain itu, pendampingan juga dilakukan melalui konsultasi secara pribadi oleh guru dengan tim pengabdian di luar waktu pertemuan kelompok. Konsultasi ini berkaitan dengan perbaikan dari desain pembelajaran yang dirancang. Materi konsultasi adalah desain pembelajaran. Kemudian, implementasi di kelas yang dilakukan di luar waktu pertemuan kelompok didampingi oleh tim pengabdian. Implementasi berkaitan dengan penggunaan aplikasi wordwall dalam pembelajaran menggunakan desain pembelajaran yang telah dibuat.

\section{Hasil Pelaksanaan dan Diskusi}

Kegiatan pengabdian masyarakat yang dilakukan ini meliputi kegiatan pelatihan dan pendampingan implementasi aplikasi wordwall dalam pembelajaran matematika. Berikut akan dipaparkan hasil pelaksanaan kegiatan yang dimaksud.

\subsection{Pelatihan}

Kegiatan pelatihan dilakukan secara tatap muka (offline) selama 2 hari pada hari Kamis tanggal 05 Agustus 2021 dari pukul 08.00-16.00 WITA sampai hari Jumat tanggal 06 Agustus 2021pukul 08.00-16.00 WITA. Peserta kegiatan berjumlah 35 orang guru dan pegawai SD Inpres Maulafa. Pelatihan dilakukan dalam bentuk pemaparan materi, tanya jawab, diskusi dan simulasi, serta kerja kelompok. Pada bagian ini, kegiatan dimulai dengan pemaparan materi oleh tim pengabdian. Materi yang diberikan dimaksudkan untuk mendukung pemahaman konseptual dan praktis guru-guru terkait pembelajaran interaktif, pembelajaran tematik, tingkat perkembangan peserta didik SD, media pembelajaran, dan pengenalan aplikasi wordwall sebagai media pembelajaran berbasis teknologi. Pemaparan materi tersebut kemudian dilanjukan dengan diskusi terkait materi yang telah disajikan. Guru-guru memberikan respon positif terkait materi yang disajikan. Hal ini terlihat dari keaktifan dan partisipasi guru dalam sesi diskusi dan tanya jawab.
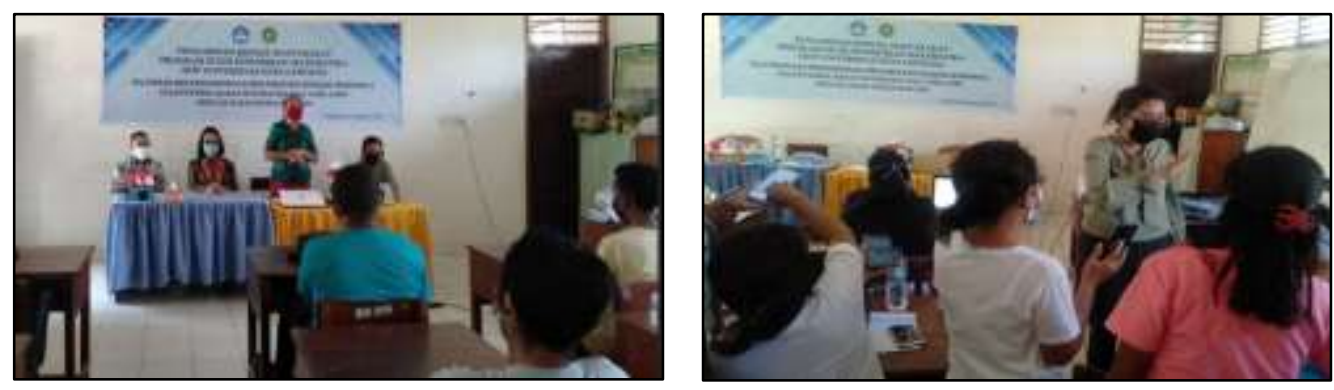

Gambar 1. Pemaparan materi dan diskusi oleh pemateri dan peserta

Selain pemaparan materi yang bersifat teoritis, dilakukan juga demonstrasi dan simulasi praktis terkait perancangan media pembelajaran dengan aplikasi wordwall. Guru-guru peserta menyimak simulasi yang dilakukan, kemudian mencoba untuk mensimulasikan secara berkolompok. Dengan pendampingan tim pengabdian, simulasi secara berkelompok kemudian dilanjutkan dengan simulasi secara mandiri. Sehingga guru-guru dapat merancang dan mendesain media berbasis aplikasi wordwall. Distribusi materi yang diberikan pada kegiatan pelatihan disajikan pada Tabel 1 . 
Tabel 1. Time schedule penyajian materi pelatihan

\begin{tabular}{lll}
\hline \multirow{2}{*}{ Hari, Tanggal } & \multicolumn{1}{c}{$\begin{array}{c}\text { Waktu } \\
\text { (WITA) }\end{array}$} & Materi \\
\hline Kamis, \\
2021 & $08.00-09.30$ & Perkembangan Kognitif Siswa SD \\
\cline { 2 - 3 } & $09.30-11.00$ & Pembelajaran Interaktif dan Inovatif \\
\cline { 2 - 3 } & $11.00-12.30$ & Media Pembelajaran dan Teknologi pembelajaran \\
\cline { 2 - 3 } & $13.00-14.30$ & $\begin{array}{l}\text { Peran guru dalam memanfaatkan teknologi dalam } \\
\text { pembelajaran tematik }\end{array}$ \\
\hline Jumat, & $14.30-16.00$ & Diskusi dan Simulasi Perancangan Media Pembelajaran \\
\hline 021 & $08.00-09.30$ & $\begin{array}{l}\text { Analisis konten berbasis pembelajaran tematik bagi } \\
\text { guru SD }\end{array}$ \\
\cline { 2 - 3 } & $09.30-11.00$ & Mengenal aplikasi wordwall dan fitur-fiturnya \\
\cline { 2 - 3 } & $11.00-12.30$ & Simulasi penggunaan aplikasi wordwall \\
\cline { 2 - 3 } & $13.00-14.30$ & $\begin{array}{l}\text { Merancang media pembelajaran dengan aplikasi } \\
\text { Wordwall }\end{array}$ \\
\hline & $\begin{array}{l}\text { Simulasi pengembangan media pembelajaran dengan } \\
\text { aplikasi Wordwall }\end{array}$ \\
\hline
\end{tabular}

Dari kegiatan pelatihan tampak bahwa guru memang belum menguasai cara pengembangan media pembelajaran yang baik, khususnya media pembelajaran berbasis teknologi. Hal ini terutama karena guru belum terbiasa memanfaatkan teknologi sebagai alternatif media pembelajaran. Hal ini pun tergambar dari pertanyaan yang ditanyakan secara antusias oleh peserta seputar pemanfaatan media pembelajaran dalam pembelajaran matematika pada sesi tanya jawab dan diskusi. Secara garis besar inti dari pertanyaan para peserta dapat dirangkum sebagai berikut. (1). Bagaimana langkah penyusunan media pembelajaran yang baik; (2). Apa saja media pembelajaran yang mudah dioperasikan; (3). Bagaimana mengintegrasikan konten dalam aplikasi wordwall; (4). Bagaimana merancang media menggunakan wordwall yang sederhana tetapi tetapi menarik; (5). Dan beberapa pertanyaan lain yang terkait teknis penggunaan aplikasi wordwall.

Beberapa pertanyaan yang diajukan peserta dijelaskan oleh pemateri dengan baik dan lengkap sehingga peserta mendapat feedback dan pengetahuan yang lengkap. Adapun beberapa pertanyaan peserta terutama terkait implementasi aplikasi wordwall dalam pembelajaran dan pertanyaan praktis lainnya tidak hanya dijelaskan secara teoritis dan konseptual oleh pemetari tetapi juga ditindaklanjuti melalui demonstrasi dan simulasi sehingga peserta dapat memahaminya secara baik dan utuh. 

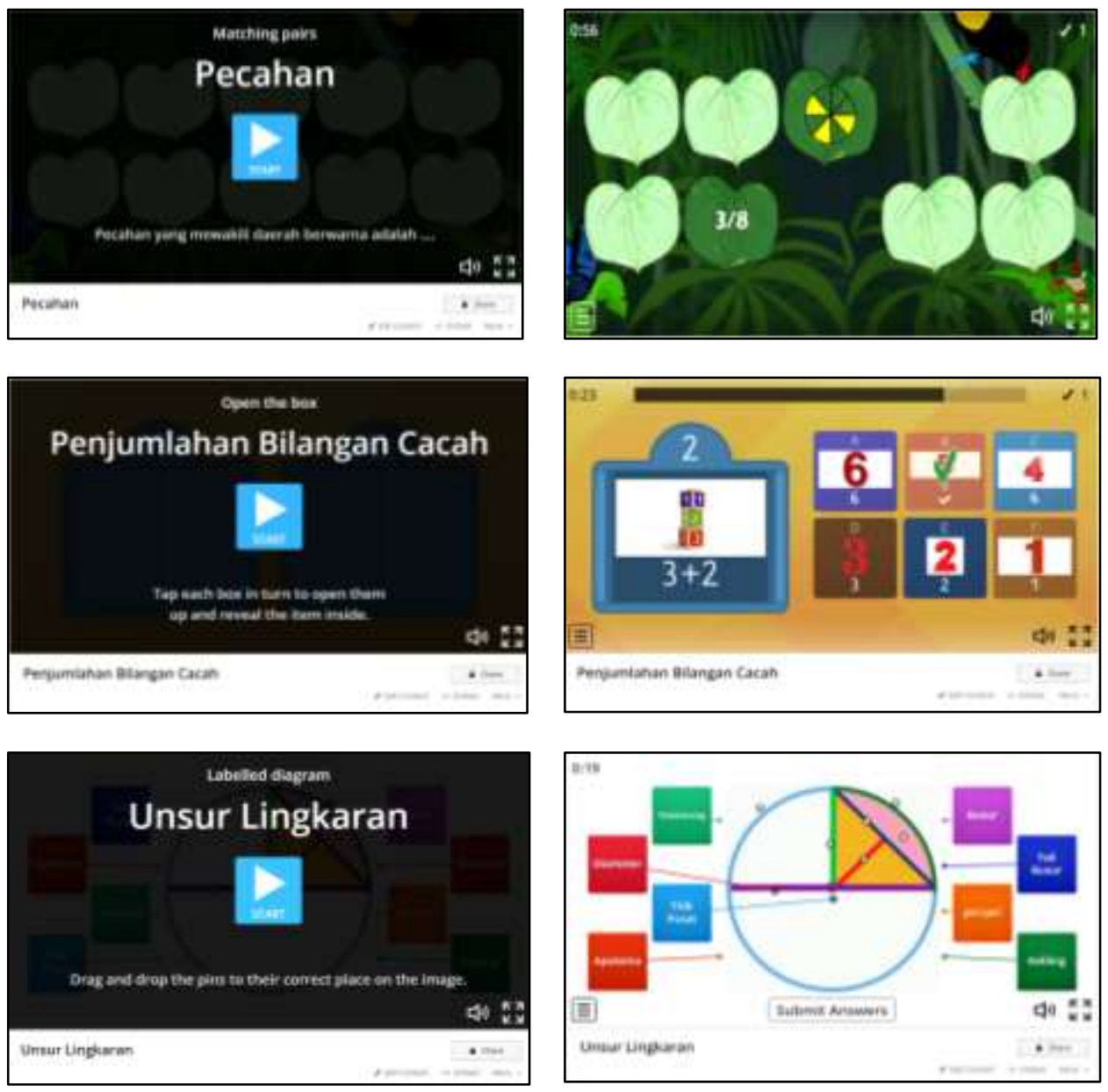

Gambar 2. Desain media berbasis aplikasi wordwall dari beberapa peserta guru

\subsection{Pendampingan}

Setelah pemaparan materi dan peserta mendapatkan berbagai informasi dan pengetahuan baik konseptual maupun praktis terkait implementasi aplikasi wordwall dalam pembelajaran matematika SD, selanjutnya peserta diberikan kesempatan untuk mengembangkan media pembelajaran berdasarkan analisis KD (Kompetensi Dasar) dan Tema tertentu. Guru secara individual dan berkelompok melakukan analisis KD dan Tema sehingga dapat merancang desain pembelajaran tematik matematika dengan memanfaatkan aplikasi wordwall sebagai media pembelajaran. Pada tahap ini, tim pengabdian melakukan pendampingan bagi para guru untuk mengembangkan desain pembelajaran yang dimaksud terutama dalam hal pengembangan dan implementasi media berbasis aplikasi wordwall.

Tim PKM melakukan pendampingan terhadap hasil pengembangan dan implementasi produk media pembelajaran yang telah dihasilkan guru pada tanggal 19 Agustus 2021. Dari pedampingan tersebut ternyata hanya ada 21 orang guru yang hadir dari 35 guru yang hadir 
pada saat pelatihan. Adapun guru-guru yang tidak hadir disebabkan karena ada kesibukan lain yang tidak bisa ditinggalkan. Sehingga ada 21 media berbasis aplikasi wordwall yang telah dibuat oleh guru-guru di SD Inpres Maulafa. Berdasarkan hasil pengembangan media berbasis aplikasi wordwall oleh guru ini, tergambar bahwa guru-guru telah mampu merancang media pembelajaran yang sesuai dengan KD dan Tema yang telah dianalisis sebelumnya. Selain itu, media yang dihasilkan juga dapat dimanfaatkan secara praktis dalam desain pembelajaran matematika tematik bagi siswa SD.

Selain pendampingan pada saat pengembangan media, pendampingan juga dilakukan bagi guru untuk mengimplementasikan desain pembelajaran yang memanfaatkan aplikasi wordwall yang telah dibuat. Pendampingan dilakukan dengan memberikan konsultasi dan catatan terhapap desain pembelajaran yang dirancang guru dan praktik implementasi salah satu guru. Secara umum, materi dan kompetensi dalam pembelajaran tersampaikan dan berjalan dengan baik. Guru juga mampu memanfaatkan aplikasi wordwall dalam pembelajaran yang dilakukan dengan baik serta terlihat antusias siswa dalam mengikuti pembelajaran. Berdasarkan desain dan praktik salah satu guru, dapat dilihat bahwa guru mampu mengimplementasikan aplikasi wordwall dalam pembelajaran matematika SD. Meskipun demikian, guru juga masih perlu beradaptasi dan secara berkelanjutan melaksanakan pembelajaran yang memanfaatkan media pembelajaran berbasis aplikasi wordwall dalam pembelajaran matematika.

Berdasarkan hasil pelatihan dan pendampingan yang dilakukan dapat dikatakan bahwa kegiatan pengabdian masyaratkat dalam bentuk "Pelatihan dan Pendampingan Implementasi Aplikasi Wordwall dalam Pembelajaran Matematika Bagi Guru Kelas Rendah Sekolah Dasar Inpres Maulafa Kota Kupang" berjalan dengan baik dan lancar. Hasil kegiatan ini memberikan potret dan gambaran bahwa secara umum guru-guru belum terbiasa dengan pembelajaran yang memanfaatkan media teknoogi dalam pembelajaran. Hal ini dikarenakan guru-guru belum memiliki pengetahuan yang cukup memadai terkait berbagai media berbasis teknologi yang dapat dimanfaatkan dalam pembelajaran, sarana dan prasarana yang kurang memadai (Syah Ali, 2020), serta budaya pembelajaran konvensional yang berlangsung selama ini. Melalui kegiatan pelatihan ini, guru-guru menjadi paham dan lebih termotivasi untuk belajar dan mulai memanfaatkan media pembelajaran berbasis teknologi. Secara khusus, antusias guru dalam memanfaatkan media berbasis aplikasi wordwall dalam pembelajaran matematika terlihat selama kegiatan ini. Hal ini tidak terlepasa dari persepsi dan respon guru yang positif terhadap aplikasi wordwall yang interaktif, mudah digunakan, dan multifungsi dalam arti dapat digunakan juga sebagai instrument penilaian selain sebagai sumber dan media belajar. Sebagaimana juga ditegaskan Sherianto (2020) bahwa aplikasi wordwall merupakan aplikasi yang bisa dijadikan sebagai media belajar, sumber belajar, serta alat penilaian bagi guru dan siswa.

Lebih lanjut, melalui kegiatan pelatihan dan pendampingan yang dilakukan guru menjadi mampu merancang dan mendesain media pembelajaran berbasis aplikasi wordwall berdasarkan analisis KD dan tema yang diberikan. Secara umum media pembelajaran yang dihasilkan guru dalam bentuk desain media berbasis aplikasi wordwall dipandang baik dan sesuai dengan KD dan tema yang diberikan. Median berbasis aplikasi wordwall yang telah dibuat guru kemudian diimplementasikan dalam pembelajaran matematika sesuai desain pembelajaran yang telah dikembangkan guru juga. Pengembangan media yang baik ini diharapkan dapat mendorong motivasi dan prestasi belajar siswa. Berdasarkan hasil 
pendampingan dapat terlihat bahwa media berbasis aplikasi wordwall yang dihasilkan guru dapat dimanfaatkan dengan baik dalam pembalajaran yang dilakukan. Siswa juga tampak antusias dan bersemangat dalam pembelajaran yang memanfaatkan aplikasi wordwall. Hal ini pun senada dengan temuan Nissa \& Renoningtyas (2021) bahwa pemanfaatan wordwall dapat meningkatan minat dan keaktifan siswa. Lebih lanjut, hal ini dapat memungkinkan adanya peningkatan prestasi belajar sisiwa (Wafiqni \& Putri, 2021).

\section{Kesimpulan}

Program pelaksanaan dan pendampingan PKM telah diselenggarakan dengan baik dan berjalan dengan lancar sesuai dengan rencana kegiatan yang telah disusun meskipun belum semua peserta pendampingan menguasai dengan baik materi yang disampaikan. Kegiatan ini mendapat sambutan sangat baik terbukti dengan keaktifan peserta mengikuti pendampingan dengan tidak meninggalkan tempat sebelum waktu pelatihan berakhir.

Berdasarkan hasil kegiatan yang telah dilakukan juga dapat disimpulkan bahwa kegiatan ini dapat membantu para guru mengatasi masalah dalam merancang pembelajaran tematik. Selain itu, kegiatan ini juga dapat menambah pengetahuan para guru tentang penerapan teknologi untuk membuat media pembelajaran berupa media pembelajaran daring matematika SD yang inovatif yakni melalui pelatihan teknis membuat media pembelajaran dengan aplikasi wordwall dalam pembelajaran matematika bagi guru-guru pada sekolah mitra. Lebih lanjut, kegiatan ini juga telah mampu menambah wawasan dan kemampuan guru untuk mengimplementasikan media dalam kegiatan pembelajaran yakni melalui pendampingan membuat desain pembelajaran menggunakan aplikasi wordwall dan pendampingan pelaksanaan (desain) pembelajaran menggunakan media wordwall.

\section{Daftar Pustaka}

Nissa, S. F., \& Renoningtyas, N. (2021). Penggunaan Media Pembelajaran Wordwall untuk Meningkatkan Minat dan Motivasi Belajar Siswa pada Pembelajaran Tematik di Sekolah Dasar. Edukatif: Jurnal Ilmu Pendidikan, 3 (5), 2854 - 2860.

Sari, P. M., \& Yarza, H. N. (2021). Pelatihan Penggunaan Aplikasi Quizizz Dan Wordwall Pada Pembelajaran IPA Bagi Guru-Guru SDIT Al-Kahfi. SELAPARANG: Jurnal Pengabdian Masyarakat Berkemajuan, 4 (2), 195-199.

Syah Ali, R. H. (2020). Dampak Covid-19 Pada Pendidikan Di Indonesia: Sekolah, Keterampilan, Dan Proses Pembelajaran. Salam: Jurnal Sosial Dan Budaya Syar-I, 7 (5), 395-402. http://dx.doi.org/10.15408/sjsbs.v7i5.15314

Undang-Undang Nomor 20 Tahun 2003 tentang Sistem Pendidikan Nasional.

Wafiqni, N., \& Putri, F. M. (2021). Efektivitas Penggunaan Aplikasi Wordwall dalam Pembelajaran Daring (Online) Matematika pada Materi Bilangan Cacah Kelas 1. Elementar (Elementary of Tarbiyah): Jurnal Pendidikan Dasar, 1(1), 68-83. 


\section{Copyrights}

Copyright for this article is retained by the author(s), with first publication rights granted to the journal.

This is an open-access article distributed under the terms and conditions of the Creative Commons Attribution license (http://creativecommons.org/licenses/by/4.0/) 